\title{
Determination of Smartphone Users' Perceptions of Branded Mobile Applications in Turkey
}

\author{
Niyazi Gümüş, Kastamonu University, Turkey
}

\begin{abstract}
Having numerous features thanks to advancements in digital technology, smartphones make life easier for users who today can conduct their activities and transactions independently of time and place by using a wide range of branded mobile applications (apps) on sports, finance, shopping and health etc. Through these apps, brands have the opportunity to reach users directly, interact with them and make customized offers. In order for brands to maximize their benefits from their own mobile apps, it is undoubtedly necessary to find out about smartphone users' perceptions of those branded mobile apps. Therefore, the aim of this study is to determine smartphone users' perceptions of branded mobile apps. In line with this purpose, face-to-face surveys were conducted in November-December 2016 with 437 students from Kastamonu University. Based on the results, smartphone users' perceptions of branded mobile apps were grouped under the factors of facilitation, stimulation of purchase desire, customization and post-purchase trust.
\end{abstract}

Keywords: Mobile applications, brands, smartphone, consumer perception

* This is an improved version of the report presented at the 2nd Economic and Market Researchs Conference held in Kocaeli/Turkey on 24-25 March 2017. 


\section{Introduction}

With advancements in technology, smartphones, tablets, computers and personal digital assistants (PDAs) are becoming more and more widespread. These mobile devices are so widely used that we can see at least one of these devices if we just glance around. These devices enable us to have real-time access to any kind of information and service independently of time and place. As the technology used in these devices advances, users can benefit from these devices in many more areas, especially shopping, banking and entertainment. The number of mobile phone users worldwide is estimated to be 7.3 billion in 2016 while the number of mobile users in Turkey is 71.8 million as of 2015 (www.itu.int, 2016). The figures indicate that the mobile commerce market will show significant improvements over the coming years. The development of e-commerce over mobile phones and constant availability of and access to smart devices have attracted the attention of marketing experts, who have thereupon sought ways to impress consumers through a variety of iOS and Android apps which have been developed in recent years for mobile devices by rapidly-growing brands. These branded apps are software systems designed to run on smartphones, tablets and other mobile electronic devices. With rapid advancements in technology, these branded apps facilitate our lives considerably while meeting our everyday needs in both personal and professional domains. Users meet their needs through these branded apps in a wide variety of areas such as communication, education, business, entertainment, medicine, finance, travel, public services, social activities and transportation.

This study primarily addresses studies on the concept of mobile apps, apps in the world and in Turkey, and understanding the effect of these apps on consumer purchase decisions. The second part of the study focuses on the results of the field research and analyzes consumers' use of branded mobile apps and examines their perceptions of these apps.

\section{Concept of Mobile Apps}

Today's fierce competition environment forces brands and companies to develop new products and services in order to reach their target groups more effectively. The latest platform which brands make use of in this context is iOS and Android branded mobile apps. The branded app is generally defined as a software program which is downloadable to mobile devices and brings the name, logo or symbol of the brand into the forefront throughout the user experience (Zhao and Balague, 2015: 305). Another study defines the branded app as 
another form of interactive advertising that is similar to, however, potentially more attractive than web sites and rich media banner advertisements (Bellman et al., 2011: 192). In another study, smartphone apps are defined as software applications designed to run on smartphones, tablets and other mobile devices (Siuhi and Mwakalonge, 2016). In the light of these definitions, it would not be wrong to define branded mobile apps as software that enables customers to communicate directly with brands and make purchases independently of time and place.

Unlike traditional online and mobile advertising such as banner ads, which are provided by advertisers, these branded mobile apps are ready-to-use services which are activated by users downloading them directly to their smartphones (Kim et al., 2013). Attracting a great deal of attention of brands, these mobile apps have become accessible and available anytime and anywhere via mobile devices as a result of rapid advancements in mobile technology. Moreover, a variety of user-specific branded apps can be offered with the processing of personal information. Standing out among portable devices, smartphones have more features than regular mobile phones. Smartphones have Microsoft Windows, Mac OSX, Linux, Android and iOS mobile operating systems similar to those used on computers (Özkoçak, 2016). The most innovative companies, brands, banks and technology firms in the world (Olmo and Jimenes, 2014: 73) not only establish a connection with their customers through advertisements but also offer useful services and tools to satisfy their customers' needs, and gain their trust and loyalty. Developed by the brands which are cognizant of technological advancements and changes in consumer trends, mobile apps help those brands to get across their messages to customers, to connect with their target audience, to provide a useful service, to interact with consumers and to create customer loyalty in a crowded market. Studies show that more than $50 \%$ of customers who regularly use a branded app are more likely to purchase from the company of that brand (Reddy, 2015).

\section{Mobile App Consumer Relationship}

Mobile apps offers great opportunities for developing new strategies to the brands which actively use mobile technologies or recognize the importance of mobile. In the coming years, mobile apps will advance very rapidly with changing consumer behavior. Only firms will be able to adapt to this transformation (Zhao and Balague, 2015: 305). Mobile apps have significant benefits for firms and brands; customers can easily access information, entertain 
themselves, receive customized coupons, and experience service while on the go. Moreover, interactive features contribute to the improvement of positive consumer attitudes toward brand, purchase intent, and ultimate purchase behavior as well as deepening consumer-brand engagement. The adoption of branded apps has a positive impact on purchase. Downloading and using a well-designed branded app stimulates customers' positive attitudes toward that brand's products or services, and increases the frequency of purchase and amount of spending (Kim et al., 2015: 31). Branded mobile apps provide far more interactive advertising and marketing communications than traditional websites (Kim and $\mathrm{Yu}, 2016$ : 77). Entertainment, functionality, information, socialization, intellectual excitement, following a trend and learning are the main reasons for consumers' use of branded mobile apps (Zhao and Balague, 2015: 306). More specifically, branded mobile apps for smartphones offer consumers the opportunity to experience brands directly or indirectly while providing brands with the opportunity to simultaneously implement traditional mass marketing and personal marketing activities (Kim and $\mathrm{Yu}, 2016:$ 77). One of the reasons for the popularity of branded apps as a part of marketing activities is the high level of user involvement rendering the advertising messages in this platform very convincing (Zhao and Balague, 2015: 305). Branded apps for smartphones allow real-time communication between companies and consumers, making feedback possible anytime and anywhere. With the integration of new technologies, branded apps for smartphones enable consumers to enjoy more interactive experiences than other marketing communication tools can offer (Kim and $\mathrm{Yu}, 2016$ : 79). Branded mobile apps are considered a valuable marketing communication tool that connects consumers effectively to brands (Kim et al., 2013). Apps are regarded as a great way of interacting with customers and an effective way of increasing customer loyalty. As well as bringing in mobile users who make purchases on a regular basis, another advantage of interacting with customers is making the purchasing journey more valuable for the customer. Brands which understand the importance of interaction as the main driving force behind sales growth and recognize the profitability of creating a loyal customer rather than having a large number of customers are now thinking about converting one-time purchasers into lifetime subscribers. At this point, it is recommended that brands analyze their customer profile well and share informative content which is relevant with this profile (DigitalAge, 2016). Mobile apps make significant contributions to companies in terms of creating value, providing new demand, enhancing productivity, supporting information sharing and gaining advantage in the face of competition (Ehrenhard et al., 2016: 1). Branded mobile apps have a great effect on customers' positive 
attitudes toward brands, however, their effect on purchase intent is not so great (Bellman et al., 2011: 198). High degree of interaction between users and a brand is considered to be directly proportionate to the effectiveness of brand-related messages in the app (Kim et al., 2013). Consumers' interaction with branded mobile apps can be an important source of value for the consumer as well as a feature that can affect future satisfaction and purchase intent. It is, therefore, important to focus on points of importance for consumers in the interaction process, to make value-driven proposals to them and to improve decision-making processes (Alnawas and Aburub, 2016).

\section{Worldwide Examples}

The number of branded mobile apps has rapidly increased in recent years. The most important reason for this is undoubtedly the increase in the use of smart devices throughout the world in recent years. As the number of especially smartphone users increases, the number of companies and brands trying to reach consumers through these apps will also increase. A global study conducted by Deloitte (2015) reports that smartphone ownership was $52 \%$ in $2012,62 \%$ in 2013 and $65 \%$ in 2014 , indicating that there is a rapid increase in smartphone ownership worldwide. A study carried out by ComScore shows that $55 \%$ of the time spent shopping online is via mobile devices. $45 \%$ of this online shopping is performed using smartphones and $10 \%$ using tablets. Brands' ability to offer a good experience has a critical impact on rates of transition of customers to basket shopping as the same study shows that disruptions in mobile user experience increase by $60 \%$ the likelihood of users to leave the app before purchasing the products in their shopping carts (Monitise, 2015). The study conducted worldwide by Emarketer (2013) shows that $43 \%$ of mobile device users use branded mobile apps to keep informed about products, stores or companies while $41 \%$ of them use those apps to get discounts and coupons. In the research carried out by WeAreSocial (2016), 86\%, 56\% and $11 \%$ of the participants stated that they had a mobile phone, a smartphone and a tablet, respectively. $24 \%$ of the respondents stated that they had purchased a product via their mobile devices in the past month. In addition, $35 \%$ of the respondents stated that they used mobile banking apps. According to another study on online shopping via mobile apps, the most important factors affecting purchase decisions of smartphone users are lucrative offers (discounts, sales promotions, etc.) (67\%), opportunity to find the physical location of a store using their mobile device (60\%) and purchasing products directly through their mobile devices (58\%) (Adobe, 2013). Another study conducted by 
Forrester (2015) with 511 participants in the US reports that participants use smartphones almost everywhere and $39 \%$ of them own 1 or $2 ; 27 \% 2$ or $3 ; 10 \%$ between 6 and 10 ; and $3 \%$ more than 10 mobile apps on their smartphones. $30 \%$ of the participants state that they have purchased a product using their smartphones within the last three months. The study also reports that the participants prefer branded mobile apps to websites as the former are more useful, faster, more fun, have more customized content and affordable offers than the latter (Forrester, 2015). Another research conducted with 8470 participants on a global scale reveals that users delete apps in their devices when they lose interest in branded mobile apps and that discounts are the most motivating factor in almost every sector for stimulating the reengagement of users. In the same study, $45 \%$ of the participants state that they use mobile apps to search for more information, $29 \%$ state that they use mobile apps to make purchases, and $43 \%$ state that mobile apps enable constant interaction with brands (thinkwithgoogle.com, 2015).

\section{Examples from Turkey}

With a rapid increase in smartphone sales and in the number of smartphone users, mobile apps have attracted the attention of marketers as an attractive platform for marketing communications (Kim et al., 2013). For example, as of March 2016, there are 73.807.321 mobile subscribers in Turkey corresponding approximately to $93.7 \%$ penetration rate. Launched in July 2009, 3G service reached 65.949 .652 subscribers by the end of March 2016. The analysis of the first quarter of 2016 indicates that $51 \%$ of the mobile subscribers are prepaid subscribers and that the rate of postpaid subscribers increased from $45.5 \%$ to $49 \%$ within the last year (Information and Communication Technologies Authority, 'ICTA', 2016). Turkey is in the top three ranks in online shopping via mobile devices together with China and United Arab Emirates. In Turkey where e-commerce rapidly shifts to mobile platform, the annual growth rate of mobile commerce is 3 times that of e-commerce. $53 \%$ of consumers in Turkey state that they used their smartphones for the purchases they made in 2014. Mobile shopping apps have a big part in consumers' lives. 64\% of smartphone users use mobile apps while 52\% use mobile browsers to make purchases. Two main reasons behind user preference for mobile apps over mobile sites are "usability" and "speed" (DigitalAge, 2016). Websites of 525 advertisers from Germany, Ireland, Netherlands, Poland, Serbia, Spain and Turkey were examined in a study conducted by the IAB Europe in September 2016. The results of the study show that more than half of the retail websites and 
more than two thirds of the finance companies have their own mobile apps, indicating that Turkey is prominent in Europe in the area of internet banking and mobile banking applications. The study also points out that Poland (52\%) and Turkey (48\%) have the biggest share among the countries with banking apps for iOS and Android in Europe (iabeurope, 2016).

User experience of online shopping sites in Turkey was evaluated by another mobile consumer survey based on the variables of first impression, browse/search, purchase and brand-user interaction. User interface, which is another evaluation criterion, consists of compliance with brand identity, compliance with mobile design standards, content and visual harmony, and mobile specific experiences. Based on the criteria stated above, Hepsiburada, N11, Teknosa, Markafoni and HürriyetEmlak were selected as the most successful sites in the categories of e-commerce, marketplace, electronics, fashion/accessories and real estate advertisement, respectively. The same study also reports that 23 of the 25 popular online shopping sites in Turkey have iPhone apps and 22 of them have Android apps (Monitise, 2015). A study carried out in Turkey reports that $85 \%$ of the participants use their smartphones to browse shopping sites/apps, and $32 \%$ of the participants state that they prefer smartphones to other devices to browse shopping sites/apps. Mobile phones have become indispensable tools for users (Kizgin and Benli, 2013) so much so that mobile phone users around the world check their mobile phones 150 times a day on average (Lieb and Szymanski, 2014: 5) while mobile phone users in Turkey check their mobile phones once every 15 minutes, in other words, 70 times a day (Deloitte, 2015).

\section{Brand and Mobile App Relationship}

When customers use a branded app to interact with a retailer, there are numerous marketing activities to be tailored to the needs of the customers. In this case, intensive use of marketing activities offers tremendous opportunities for retailers to attract customers and to increase sales. If retailers provide valuable apps for their customers and improve their shopping experience, then customers will purchase their products (Apptentive, 2014).

Firms and brands use mobile apps as an additional communication channel to increase brand awareness and brand experience of the target audience, to attract new customers and to 
strengthen the brand loyalty of their current customers (Kim et al., 2015: 29). Some other objectives of branded mobile apps are communication, customer service, sales, product innovation and marketing research. The objective of communication includes brand values, brand knowledge, product information, communication with consumers, thus, improving brand image and raising brand awareness. The objective of customer service is to interact with current and potential customers. While brands aim to create an entirely new purchasing experience and interaction thanks to the sales objective of mobile apps, they also offer users access to innovations with a range of services such as location awareness and product customization.

In the context of product innovation, branded apps allow users to create new ideas for products, showing brands' openness to innovation. Finally, in the context of marketing objectives, branded apps provide firms with the opportunity to survey users directly to elicit new information. Rather than buying small banner ads, brands should concentrate on apps that add value to customers' lives and enhance their long-term interaction with the brand. At this point, it is recommended that branded mobile apps offer a unique value to the target audience, be entertaining, easy to use, and sensitive to social issues and contain various incentives in order to be successful (Gupta, 2013). Before developing any mobile app, it will be useful for brands to review the following headings for the success and sustainability of their apps (Ux Booth, 2010; Reddy, 2015);

- Users do not tolerate apps that they think open or run too slowly.

- Speed of a mobile app is more important than speed of its website version.

- Simplicity, functionality and accessibility are the key features

- Mobile app users do not want to be overwhelmed by the number of choices and distracting options while trying to reach a feature.

- The app should offer a useful, engaging and memorable experience for the target audience.

- The app should contribute to the improvement of brand awareness and loyalty.

- The app should provide customers with various advantages and facilities such as brand knowledge, product discount, etc.

- It is extremely important that the app is secure, simple, easy to use and well-designed.

- Target audience of the mobile app should be carefully determined. 
- Various marketing efforts should be planned in order to establish a connection and improve interaction between mobile app users and the brand.

\section{Research Method}

This study was carried out to elicit information on Turkish smartphone users' perceptions of branded mobile apps. Face to face interviews were carried out with 437 students from Kastamonu University in November-December 2016. The participants were selected using a convenience sampling method, which is one of the non-random sampling methods. The statements in the questionnaire were adopted and reformulated from the studies conducted by Yoo and Donthu (2001), Moital et al., (2012), and Kim and Ko (2012).

\section{Findings}

This section includes the demographic characteristics of the participants, their assessments of branded mobile apps and results of Anova test and t-test.

Table 1.Demographic Characteristics of Participants

\begin{tabular}{|c|c|c|c|c|c|}
\hline Gender & $\mathbf{F}$ & $\%$ & Monthly Average Family Income & $\mathbf{F}$ & $\%$ \\
\hline Female & 269 & 61.6 & $1000 \mathrm{TL}$ and Below & 47 & 10.8 \\
\hline Male & 168 & 38.4 & $1001 \mathrm{TL}-2000 \mathrm{TL}$ & 184 & 42.1 \\
\hline Age & $\mathbf{F}$ & $\%$ & $2001 \mathrm{TL}-3000 \mathrm{TL}$ & 122 & 27.9 \\
\hline $16-18$ & 52 & 11.9 & $3001 \mathrm{TL}$ and More & 84 & 19.2 \\
\hline $19-21$ & 254 & 58.1 & $\begin{array}{l}\text { Monthly Average } \\
\text { Income }\end{array}$ & $\mathbf{F}$ & $\%$ \\
\hline $22-24$ & 119 & 27.2 & $250 \mathrm{TL}$ and Below & 85 & 19.5 \\
\hline $25-27$ & 9 & 2.1 & $251 \mathrm{TL}-500 \mathrm{TL}$ & 195 & 44.6 \\
\hline 28 and older & 3 & .7 & $5001 \mathrm{TL}-750 \mathrm{TL}$ & 87 & 19.9 \\
\hline Academic Unit & $\mathbf{F}$ & $\%$ & $751 \mathrm{TL}-1000 \mathrm{TL}$ & 44 & 10.1 \\
\hline $\begin{array}{l}\text { Faculty of Economics and } \\
\text { Administrative } \\
(\text { FEAS) }\end{array}$ & 71 & 16.2 & $1000 \mathrm{TL}$ and More & 26 & 5.9 \\
\hline Faculty of Education & 49 & 11.2 & Additional Income & $\mathbf{F}$ & $\%$ \\
\hline Faculty of Arts and Sciences & 51 & 11.7 & Scholarship & 78 & 17.8 \\
\hline Faculty of Tourism & 27 & 6.2 & Loan & 177 & 40.5 \\
\hline Faculty of Health Sciences & 39 & 8.9 & Other & 182 & 41.6 \\
\hline Faculty of Communication & 34 & 7.8 & Work Status & $\mathbf{F}$ & $\%$ \\
\hline $\begin{array}{l}\text { Faculty of Engineering and } \\
\text { Architecture }\end{array}$ & 59 & 13.5 & Unemployed & 376 & 86.0 \\
\hline Faculty of Theology (FT) & 36 & 8.2 & Sporadic & 46 & 10.5 \\
\hline
\end{tabular}




\begin{tabular}{lcclcrr} 
Vocational School & 67 & 15.3 & Part-time & 9 & 2.1 \\
\hline Institute of Social Sciences & 4 & .9 & Full-time & 6 & 1.4 \\
\hline Total & $\mathbf{4 3 7}$ & $\mathbf{1 0 0}$ & Total & $\mathbf{4 3 7}$ & $\mathbf{1 0 0}$ \\
\hline
\end{tabular}

Table 1 contains the demographic characteristics of the participants. 437 students from various academic units participated in the study. More than half of the participants are women. The majority of the participants are between the ages of 19 and 21 . The family income and personal income of the majority of the participants lie within the range of 1000 TL to $2000 \mathrm{TL}$ and $251 \mathrm{TL}$ to $500 \mathrm{TL}$, respectively. Table 1 also demonstrates that a significant portion of the participants do not work and $41.6 \%$ of the participants have income in addition to scholarship or student loan.

Table 2. Mobile App Usage States of Participants

\begin{tabular}{|c|c|c|c|c|c|}
\hline Frequency of using mobile apps & $\mathbf{F}$ & $\%$ & $\begin{array}{l}\text { What kind of apps do you } \\
\text { have on your mobile phone? }\end{array}$ & $\mathbf{F}$ & $\%$ \\
\hline Every day & 350 & 80.1 & Clothing & 73 & 16.7 \\
\hline Several times a week & 14 & 3.2 & Shoes & 39 & 8.9 \\
\hline Once a week & 6 & 1.4 & Technology & 126 & 28.8 \\
\hline Sometimes & 59 & 13.5 & Sports & 77 & 17.6 \\
\hline Never & 8 & 1.8 & Food & 14 & 3.2 \\
\hline $\begin{array}{l}\text { How many branded apps do you } \\
\text { have on your mobile phone? }\end{array}$ & $\mathbf{F}$ & $\%$ & Automobile & 38 & 8.6 \\
\hline $\mathbf{0}$ & 12 & 2.7 & Cosmetics & 33 & 7.5 \\
\hline $1-2$ & 90 & 20.6 & Social Media & 345 & 78.9 \\
\hline $3-5$ & 152 & 34.8 & Other & 82 & 18.7 \\
\hline 6-8 & 85 & 19.5 & $\begin{array}{l}\text { Have you ever made } \\
\text { purchases } \\
\text { via branded mobile apps? }\end{array}$ & $\mathbf{F}$ & $\%$ \\
\hline \multirow[t]{4}{*}{9 or more } & 98 & 22.4 & Never & 188 & 43.0 \\
\hline & & & $1-3$ times & 154 & 35.2 \\
\hline & & & 4-6 times & 34 & 7.8 \\
\hline & & & 7 times or more & 61 & 14.0 \\
\hline Total & 437 & 100 & Total & 437 & 100 \\
\hline
\end{tabular}

Table 2 presents the participants' use of branded mobile apps. Almost all of the participants state that they use mobile apps every day. Only $2.7 \%$ of the participants do not have branded mobile apps on their mobile phones. On the other hand, $22 \%$ of the participants have 9 or more apps on their mobile phones. The rate of the participants with at least $1-2$ apps is $20.6 \%$. 
The majority of the participants state that they have social media apps on their mobile phones. $43 \%$ of the participants state that they did not purchase products via mobile apps while $14 \%$ of the participants state that they purchased 7 or more products using mobile apps.

Table 3. Reasons for Participants Using Branded Mobile App

\begin{tabular}{lll}
\hline Reasons for Smartphone Users' Using Branded Mobile Apps & F & \% \\
\hline To get information regarding the brand and its products & 164 & 37.5 \\
\hline To follow entertaining contents & 156 & 35.6 \\
\hline To benefit from favorable prices & 146 & 33.4 \\
\hline To Follow discounts and promotions & 139 & 31.8 \\
\hline Favorable attitude towards the brand and its products & 38 & 8.6 \\
\hline To communicate with the brand & 38 & 8.6 \\
\hline To participate in award-winning competitions & 25 & 5.7 \\
\hline To show brand loyalty & 21 & 4.8 \\
\hline Other & 63 & 14.4 \\
\hline
\end{tabular}

Table 3 demonstrates the reasons why participants use branded mobile apps, indicating that the most important reason is "to get information regarding the brand and its products" followed by the reasons "to follow entertaining contents" and "to benefit from favorable prices" whereas "brand loyalty" is the least important reason for participants' use of branded mobile apps according to Table 3 .

Table 4. Most Downloaded Apps by Participants

\begin{tabular}{clc}
\hline Item No & \multicolumn{1}{c}{ Most Downloaded Branded Apps } & Number of \\
\hline 1 & Trendyol & 90 \\
\hline 2 & Teknosa & 56 \\
\hline 3 & Lcw & 47 \\
\hline 4 & Markafoni & 46 \\
\hline 5 & Sahibinden & 18 \\
\hline 6 & Aliexpress & 16 \\
\hline 7 & Koton & 13 \\
\hline 8 & Mavi & 11 \\
\hline 9 & Tozlu & 11 \\
\hline 10 & ZiraatBankas1 & 10 \\
\hline 11 & Letgo & 10 \\
\hline 12 & Morhipo & 10 \\
\hline 13 & Defacto & 8 \\
\hline 14 & Hepsiburada & 8 \\
\hline 15 & Gratis & 7 \\
\hline
\end{tabular}




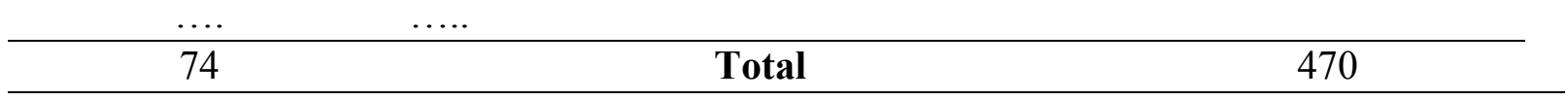

Table 4 lists the most downloaded branded mobile apps by smartphone users, showing that 437 participants downloaded and used 74 different apps 470 times. Trendyol is ranked $1^{\text {th }}$ (downloaded 90 times), Teknosa $2^{\text {nd }}$ (downloaded 56 times) and Lcw $3^{\text {rd }}$ (downloaded 47 times).

\section{Factor Analysis}

In this section, firstly, a factor analysis was performed in order to examine the participants' perceptions of branded mobile apps. Secondly, a One-Way ANOVA (Variance Analysis) was carried out in order to determine whether there is a statistically significant difference between the demographic characteristics of the participants in terms of the factors that emerged from the factor analysis.

Table 5. KMO and Bartlett's Test

\begin{tabular}{|c|c|c|}
\hline $\begin{array}{l}\text { Kaiser-Meyer-Olkin } \\
\text { Adequacy. }\end{array}$ & Measure of Sampling & .786 \\
\hline Bartlett's & ofApprox. Chi-Square & 1061.311 \\
\hline \multirow[t]{2}{*}{ Sphericity } & $\mathrm{df}$ & 55 \\
\hline & $\overline{\text { Sig. }}$ & .000 \\
\hline
\end{tabular}

The results of KMO and Bartlett's test conducted to verify sampling adequacy show that KMO value was high (0.786) and Bartlett's test result was significant (0.000), indicating that there is a strong correlation between the variables.

Table 6. Factor Analysis

\begin{tabular}{lllllll}
\hline & & \multicolumn{3}{c}{ Factors } \\
\cline { 3 - 5 } & Statements & 1 & 2 & 3 & 4 \\
\hline Facilitation & & & \\
\hline
\end{tabular}

Branded mobile apps provide installment plan options for credit .791 card purchases.

Branded mobile apps allow me to buy products that are not .769 available where I live.

Branded mobile apps make shopping possible in all circumstances $\quad .653$ without being tired. 
Discounts and promotional opportunities can be easily followed .617 using branded mobile apps.

\section{Purchase Desire}

Having brands' mobile apps on my smartphone affects my purchase $\quad .768$ decision.

Instant or daily discounts on products in branded mobile apps $\quad .745$ stimulate my purchase desire.

The ease of use of branded mobile apps stimulates my purchase $\quad .562$ desire.

\section{Customization}

\begin{tabular}{ll}
\hline Branded mobile apps provide customized information. & .875 \\
\hline Branded mobile apps provide customized services. & .858
\end{tabular}

\section{Post-Purchase Trust}

Branded mobile apps do not cause problems in terms of delivery

time.

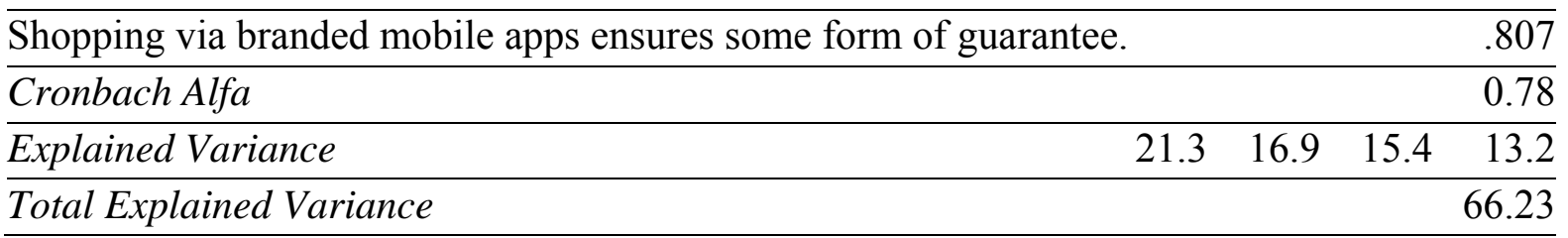

Table 6 contains the factors that emerged from the factor analysis. Four factors emerged in the analysis, which are Facilitation (1), Stimulation of Purchase Desire (2), Customization (3) and Post-Purchase Trust (4). Table 6 shows that these 4 factors explain $66.23 \%$ of the perceptions of the participants regarding branded mobile apps and that the remaining part is explained by other variables that are not included in the survey.

\section{One-Way Anova Test Results}

An Anova test was conducted to determine whether there were statistically significant differences between the variables of participants' academic units, demographic characteristics, etc. The test results for the differences are shown below. There was a statistically significant difference only between the participants' academic units in terms of "facilitation," "stimulation of purchase desire" and "customization" factors. Table 7 demonstrates the resulting differences. 
Table 7. Participants' Academic Units and Mobile App Factors Anova Table

\section{ANOVA}

\begin{tabular}{|c|c|c|c|c|c|c|}
\hline & & $\begin{array}{l}\text { Sum of } \\
\text { Squares }\end{array}$ & df & $\begin{array}{l}\text { Mean } \\
\text { Square }\end{array}$ & $\mathbf{F}$ & Sig. \\
\hline \multirow{3}{*}{ Facilitation } & Between Groups & 12,100 & 9 & 1,344 & 1,973 & ,041 \\
\hline & Within Groups & 290,904 & 427 &, 681 & & \\
\hline & Total & 303,004 & 436 & & & \\
\hline \multirow{3}{*}{$\begin{array}{l}\text { Stimulation } \\
\text { Purchase Desire }\end{array}$} & of Between Groups & 12,100 & 9 & 1,344 & 1,973 &, 041 \\
\hline & Within Groups & 290,904 & 427 &, 681 & & \\
\hline & Total & 303,004 & 436 & & & \\
\hline \multirow{3}{*}{ Customization } & Between Groups & 19,891 & 9 & 2,210 & 2,794 &, 003 \\
\hline & Within Groups & 337,817 & 427 &, 791 & & \\
\hline & Total & 357,708 & 436 & & & \\
\hline \multirow{3}{*}{$\begin{array}{l}\text { Post-Purchase } \\
\text { Trust }\end{array}$} & Between Groups & 8,176 & 9 & ,908 & 1,127 & ,342 \\
\hline & Within Groups & 344,113 & 427 & ,806 & & \\
\hline & Total & 352,289 & 436 & & & \\
\hline
\end{tabular}

A Tukey test was carried out in order to determine between which academic units the difference existed in terms of mobile app factors. The Tukey test results indicate that the students of the Faculty of Theology agree more with the factor that mobile apps facilitate shopping than those of the Faculty of Economics and Administrative Sciences (FEAS). Similarly, the students of the Faculty of Theology believe more that mobile apps stimulate purchase desire than those of FEAS. The Tukey test also reveals that the students of the Faculty of Theology and of the Faculty of Arts and Sciences agree more with the factor that mobile apps provide customization opportunities than those of the Faculty of Engineering and Architecture.

\section{T-test Results}

A t-test was conducted to determine whether there was a statistically significant difference between the two genders in terms of mobile app factors. The t-test results indicate that there is a statistically significant difference between the two genders in terms of "post-purchase trust" factor. 
Table 8. Participants' Gender Post-Purchase Trust Factor T-Test

\begin{tabular}{lrrrrrrr}
\hline \multicolumn{1}{c}{ Group } & $\mathbf{N}$ & Mean & $\begin{array}{c}\text { Standard } \\
\text { Sapma }\end{array}$ & $\mathbf{t}$ & df & p \\
\hline Woman & 269 & 3.0167 & .86640 & 2.049 & 435 & .045 \\
\hline Man & 168 & 2.8363 & .94060 & & & \\
\hline
\end{tabular}

Table 8 shows that the mean value of post-purchase trust of the women is higher than that of the men.

\section{Conclusion and Recommendations}

This study was conducted to elicit information on smartphone users' perceptions of branded mobile apps and the following conclusions were drawn:

- Nearly all participants use branded mobile apps on a daily basis. $97.3 \%$ of the participants have 1 or more branded mobile apps on their mobile phones. Moreover, the rate of participants with 9 or more applications on their mobile phones is $22 \%$.

- The majority of the participants state that they have social media-based apps on their mobile phones. Apps of clothing, technology and sports brands are more preferred by users.

- More than half of the participants have purchased 1 or more products through mobile apps. Moreover, the rate of participants who have purchased 7 or more products via mobile apps is $14 \%$. These figures clearly demonstrate the effect of mobile apps on consumers' purchase decisions.

- The reasons why the participants use branded mobile apps are "to get information regarding the brand and its products", "to follow entertaining contents" and "to benefit from favorable prices", ranking $1^{\text {st }}, 2^{\text {nd }}$ and $3^{\text {rd }}$, respectively. These three reasons give brands clues to the content of mobile apps to be developed. Apps are expected by consumers to be entertaining, advantageous and rich in information on the brand and its products.

- The results show that smartphone users' perceptions of branded mobile apps are grouped under 4 factors; facilitation, stimulation of purchase desire, customization and post-purchase trust. 
- According to the Tukey test results, the students of the Faculty of Theology agree more with mobile apps facilitating shopping than those of FEAS. Similarly, the students of the Faculty of Theology believe more in mobile apps stimulating purchase desire than those of FEAS.

These results clearly show that smartphones, as they exist today, will continue their existence with new features in the future and will have a significant impact on consumers' purchase decisions. It is, therefore, suggested that brands and businesses pay utmost attention to mobile communication, interact with consumers especially through mobile apps and concentrate on customized offers. Investments made in this area will, in return, provide enterprises and brands with sales, profit and advertising advantages. This study has focused on young people who use mobile technology extensively. It is recommended that further studies be carried out on users with different demographic characteristics. 


\section{References}

Adobe (2013) Mobile Shopping: RetailAppUsage on the Rise. https://www.adobe.com/aboutadobe/pressroom/pdfs/Mobile_Shopping_Retail_App_ Usage_on_the_Rise_Infographic.pdf. (Erişim tarihi; 16.12.2016).

Alnawas, Ibrahim andAburub, Faisal (2016) Theeffect of benefitsgeneratedfrominteractingwithbranded mobile apps on consumersatisfactionandpurchaseintentions. Journal of Retailingand Consumer Services31(2016)313-322

Apptentive (2014) TheMobileShopper Is Here. http://cdn2.hubspot.net/hubfs/232559/RetailerSurveyReport_v5.pdf?t=148184707643 0. (Erişim tarihi; 16.12.2016).

Bellman, S.. Potter, Robert F. Treleaven-Hassard, Shiree Jennifer A. Varan Robinson a \&Duane (2011) TheEffectiveness of Branded Mobile Phone Apps. Journal of Interactive Marketing 25 (2011) 191-200.

Bilgi Teknolojileri ve İletişim Kurumu (2016) Türkiye Elektronik Haberleşme Sektörü, 2016 Y1l 1. Çeyrek Ocak - Şubat - Mart. https://www.btk.gov.tr/File/?path=ROOT\%2f1\%2fDocuments\%2fSayfalar\%2fPazar_ Verileri\%2f2016-Q1.pdf (Erişim tarihi; 16.12.2016).

Deloitte (2015) Deloitte Global Mobil Kullanıcı Anketi 2015 https://www2.deloitte.com/tr/tr/pages/technology-media-andtelecommunications/articles/global-mobile-consumer-survey.html (Erişim tarihi: 14.12.2016).

Deloitte (2015) DigitalPredictions 2015 https://www2.deloitte.com/tr/tr/pages/consumerbusiness/articles/digital-predictions-2015.html. (Erişim tarihi: 14.12.2016).

DigitalAge (2016) Mobil ticarette başarı için takip edilmesi gereken trendlerhttp://digitalage.com.tr/mobil-ticarette-basari-icin-takip-edilmesi-gerekentrendler/ (Erişim tarihi; 16.12.2016).

Emarketer (2013) Brands' Mobile AppsAren'tJustAbouttheDiscounts. https://www.emarketer.com/Article/Brands-Mobile-Apps-Arent-Just-AboutDiscounts/1010100(Erişim tarihi; 16.12.2016).

Ehrenhard, Michel. WijnhovencFons, Broek, Tijsvan den andStagno, MarcZinck(2016) Unlocking how start-upscreatebusinessvaluewith mobile applications: Development 
of an App-enabled Business InnovationCycle.

TechnologicalForecasting\&SocialChange .Accepted 14 September 2016.

Forrester (2015). TheState Of Mobile AppsForRetailers.

https:/www.retailmenot.com/corp/static/filer_public/78/9c/789c947a-fe7c-46ce908a-790352326761/stateofmobileappsforretailers.pdf (Erişim tarihi; 25.12.2016).

Gupta, Sunil(2013) For Mobile Devices, ThinkApps, Not Ads. https://hbr.org/2013/03/formobile-devices-think-apps-not-ads (Erişim tarihi; 16.12.2016).

Iab Europe (2016). IAB Europe Advertiser Mobile Audit Report. http://iabeurope.eu/wpcontent/uploads/2016/09/IABEuropeAdvertiserMobileAuditReport.pdf (Erişim tarihi; 25.12.2016).

Kim, Su Jung. Wang, RebeccaJen-HuiandMalthouse, Edward C. (2015) TheEffects of Adoptingand Using a Brand's Mobile Application on Customers' SubsequentPurchaseBehavior. Journal of Interactive Marketing 31 (2015) 28-41. Kım, JunghyunandYu, Eun Ah (2016) TheHolıstıcBrandExperience Of BrandedMobileApplicationsAffectsBrandLoyalty.SocialBehaviorAndPersonality, 2016, 44(1), 77-88

Kim, Eunice, Lin, Jhih-Syuan\&YongjunSung (2013) To Appor Not to App:

EngagingConsumersviaBranded Mobile Apps. Journal of Interactive Advertising, 13(1), 53-65.

Kim,AngellaandKo, Eunju. (2012) Do socialmediamarketingactivitiesenhancecustomerequity? nempiricalstudy of luxuryfashionbrand. Journal of Business Research 65 (2012) 1480-1486

Kizgin, Y \& Benli, T. (2013)TheExamining of GSM Operators' CustomerComplaint Management(CCM) Applications in TurkeywithDiscriminant Analysis. International Journal of Business and Management; Vol. 8, No. 3; 2013.

Lieb,RebeccaandSzymanski, Jaimy(2014)Why Mobile is EssentialforBrand Marketing. https://fbcdn-dragon-a.akamaihd.net/hphotos-akxap1/t39.2365/10541001_704049666333013_307545824_n.pdf(Erişim tarihi: 14.12.2016).

Moital, Miguel, Vaughan, Roger. Edwards, JonathanAndPeres, Rita. (2012) Determinants of Intention to PurchaseOverthe Internet. Anatolia: An International Journal of TourismandHospitalityResearch Volume 20, Number 2, pp. 345-358, 2009. 
Monitse (2015) Türkiye Mobil Alışveriş Uygulamaları araştırması.

http://www.slideshare.net/PozitronMobile/monitise-trkiye-mobil-alveri-uygulamalararatrması (Erişim tarihi; 16.12.2016).

Olmo, Francisco-JavierRuız-Del and JIMÉNEZ Ana-MarıBelmonte (2014) Young People as Users of Branded Applications on Mobile Devices. Comunicar, n. 43, v. XXII, 2014.

Özkoçak, Yelda. (2012) Türkiye'de Akıllı Telefon Kullanıcılarının Oyalanma Amaçlı Tercih Ettikleri Mobil Uygulamalar. Global Media Journal TR Edition, 6 (12). Bahar/Spring 2016

Reddy, Trips (2015) 14 Brands Using Mobile AppsInstead of Ads to BuildCustomerLoyalty. https://www.umbel.com/blog/marketing/14-brands-using-mobile-apps-instead-adsbuild-loyalty/. (Erişim tarihi; 16.12.2016).

Siuh1, SaidiandMwakalonge, Judith (2016) Opportunitiesandchallenges of smart mobile applications in transportation. J. TrafficTransp. Eng. (Engl. Ed.) 2016; x (x): 1e11

Thinkwithgoogle.com (2015). Mobile App Marketing Insights:How ConsumersReallyFindandUseYourApps. https://think.storage.googleapis.com/docs/mobile-app-marketing-insights.pdf (Erişim tarihi; 26.12.2016).

UxBooth (2010) User Expectationswith Mobile Apps - CatchingupwithEffective UIhttp://www.uxbooth.com/articles/12207/ (Erişim tarihi: 14.12.2016).

Yoo, BoongheeandDonthu, Naveen(2001) Developingandvalidating a multidimensionalconsumer-basedbrandequityscale. Journal of Business Research 52 (2001) $1 \pm 14$.

Zhao, ZhenzhenandBalague, Christine(2015) Designingbranded mobile apps: Fundamentals andrecommendations. Business Horizons (2015) 58, 305-315.

Wearesocial (2016) Digital in 2016. http://wearesocial.com/uk/special-reports/digital-in2016. (Erişim tarihi; 16.12.2016).

www.itu.int (2016) ICT FactsandFigures 2016 http://www.itu.int/en/ITU-

D/Statistics/Pages/facts/default.aspx. (Erişim tarihi; 23.12.2016). 